\title{
Investigating the Students' Strategies in Developing Intercultural Communicative Competence (ICC) Model in Indonesia University Context
}

\author{
Edi \\ Universitas Negeri Makassar, Jln. Bonto Langkasa, Kampus Gunung Sari, Makassar, South Sulawesi, Indonesia \\ Basri Wello \\ Universitas Negeri Makassar, Jln. Bonto Langkasa, Kampus Gunung Sari, Makassar, South Sulawesi, Indonesia \\ Syarifuddin Dollah \\ Universitas Negeri Makassar, Jln. Bonto Langkasa, Kampus Gunung Sari, Makassar, South Sulawesi, Indonesia
}

\begin{abstract}
The study investigated the students' strategies in increasing intercultural communicative competence (ICC) model. The researchers employed qualitative research method by applying grounded theory design. The participants of this research were four students from different grade levels of English study program of STKIP Yapis Dompu-NTB. There were five data collection techniques used: interview, observation, field note, audio recording, and documentation. The result of this research indicated that the participants have different strategies to improve ICC model. The A.M. participant has sixteen strategies, the Y.A. participant has nine strategies, A.S. participant has seven strategies, and E.D participant has ten strategies.
\end{abstract}

Index Terms - ICC, students strategies, and model of strategies

\section{INTRODUCTION}

In the $21^{\text {st }}$ century, it is predicted that there are around 360 million people who speak English as the first language, amongst 375 million people use English as their second language and 750 million people learn it as a foreign language (Graddol, 2000, p. 10). Indonesia has complicated cultures. There are 726 different languages in this country (Crystal, 2000, p.4). It means that there are 23 million native speakers and 140 million second language speakers. These speakers speak with diverse cultural dialects and have a large number of international communities (Malay, Chinese, Japanese, Singapore, etc.) that made their daily interaction become more intercultural communicative competence (ICC). ICC becomes a vital issue since the human interaction occurred. Intercultural communication refers to communications between people from different ethnic, gender, social, and cultures within the same and different nation. Intercultural communication has been found within the group of the students when they communicate in daily engagement both in and outside the classroom with the increasingly diverse students' cohort. Intercultural is now ubiquitous. They occur within neighborhoods, across national borders, in face to face interactions, through mediated channels, in various sectors. Intercultural competence can end disputes, save lives, radically transform the existence of millions of people. Intercultural communication can lubricate the wheels of education, industry, and business. Intercultural competence has been defined as the ability to interact with people from different cultures (Guilherme, 2000).

Based on the preliminary observation at English study program of STKIP Yapis Dompu-NTB, it was found that the majority of the students have fairly good command of the English grammar, sentence structure, and list of vocabulary items (Lexis) but they have less competence for the language use. Lecturers tend to focus mainly on teaching the macro-language skills (speaking, listening, reading, and writing) and micro-language skills (vocabulary and grammar) without emphasizing on the increasing of the students' ICC. There are at least two important reasons for studying ICC. Firstly, it builds the personal interaction with people of different cultures in more particular manner. Intercultural communication is the process of exchanging thoughts and meanings among people of diver's cultures. Secondly, it helps the colleges and universities in designing programs aiming at increasing students' leadership. The researchers have realized how important to incorporate the culture into strategies for models of ICC. The lack of strategy to improve the attitude, knowledge, skills, and awareness (dimension of ICC) of our student, made us think about, how culture can be interestingly taught using various strategies at the institution. Lecturers cannot teach language without a strategy of intercultural background. There are many strategies for increasing ICC model. In this research, the researchers investigated the students' strategies for increasing ICC model. 
The researchers' interest in this field came from a variety of sources. Firstly it derived from our traveling experiences to increase our ICC in diverse settings, which led us to the process of examining cultural assumptions of cultural beliefs, values, and worldviews. Secondly, it came from our experiences in Malaysia when we became the presenters in an Asia TEFL and Asia EFL conferences for increasing our strategies to improve our attitude, knowledge, skills, and awareness which related to the ICC with different cultures, learning another cultures, languages, situations, environment, etc. These experiences opened up our minds towards the strategies and models of ICC of language learning for our student. The purpose of this study was to investigate the strategies used by the students of English Study Program of STKIP Yapis Dompu-NTB, Indonesia in increasing their ICC model. It attempted to identify the different strategies in accelerating the ICC model of the students.

\section{LITERATURE REVIEW}

\section{A. Culture Conceptualized}

\section{1) Definition and Perspective of the Culture}

A culture, according to Tylor (1871 as cited by Holliday, 2010) is defined as the complex blend of knowledge, customs, arts, moral, norms, beliefs and the other abilities as well as the habits those acquired by people as the member of society. Similarly, Holliday defines culture as the beliefs, values, and concepts that enable the group to understand its life and give it a clue how to live (Fay, 1996 in Holliday, 2010). While according to Nakayama (2010) culture is defined as the patterns of behavior and attitude learned by a group of people. Therefore, culture is a universal orientation system that shows the characteristics of society, organization or group. Hence, culture greatly influences the perceptions and the thinking as well as and evaluates the action of all its members. Thomas (2006 as cited by Franklin, 2009, p.14-15) contends that culture is the structure of a specific field-oriented system of action for those who feel affiliated with this culture and thus creates a prerequisite for developing its own way to cope with its environment. While Franklin (2009: 15) himself perceives that beside culture is displayed by different kinds of intermittences, in which some of them are more explicit than the others, it is also connected with the social groups where there were no individuals in the group have exactly similar cultural characteristics. Further, Franklin (2009) adds that culture influences both the behavior of people and the behavior explication. According to him, culture is gained and or built through the people's interactions.

2) Components and The Element of Culture

According to Kendall (2001, p.72) and Samovar et al. (2010, p.24), even though the details of an individual culture differ comprehensively, all cultures have similar non-material cultural components such as verbal and nonverbal symbols, norms of behavior, value systems, language styles, religious types, history and social organizations. These components contribute to both harmony and conflict in intercultural communication or a cross-cultural environment. Tuleja (2005, p.5) mentions the beliefs, values, and attitudes as the elements that as the basis for the norms and rules of social interaction, all of which translate into behavior. Knowing something about other cultures will help individuals to understand another person's worldview and the most basic assumptions he or she holds regarding others who are different. The main goal is to have more successful cross-cultural interactions, to become more culturally literate (Tuleja, 2005, p.5).

\section{B. ICC Conceptualized}

\section{1) Increasing ICC}

There are various ways to increase ICC. Durant (1997) argues that tasks assigned to schools such as interaction with members of targeted cultures, recording the testimony of members of the target culture, visiting a certain country, conducting ethnographic and survey research, searching data on history and politics and collecting statistical information. The way people dress up and the style of the target culture is one of the ways to increase the ICC of students.

According to Byram et al. (2001), to increase the students ICC can be done through cultural learning. Cultural learning is the process of comparing cultures that encourage tobe more aware of the cultural phenomena in their communities and in the target culture. Cultural learning is more emphasized on developing the ability to analyze and interpret cultural data from the target culture. Students are given the opportunity to obtain authentic data either through the exploration of resources available in their own communities or by using technology to obtain the cultural data with distant cultures. Hence, literature was considered particularly useful in developing intercultural understanding (Byram et. al., 2001). In order to be able to successfully develop ICC, teachers and organizers should consider the three separate phases of exchanges and the various activities which each part involves the preparatory phase, fieldwork phase, and follow-up phase (Byram et.al., 2002).

\section{2) Model of ICC}

The dimensions of ICC consist of attitude, knowledge, skills, and behavior (Byram, 1997, p.55). Risager (2007) as cited by Shoman and Mahmod (2011, p.36), describes the ICC in terms of ten different competencies and skills. These competencies are linguistic (lingua structural) competence, linguistic and resource competencies, translation and interpretation, textual interpretation (discourse), use of ethnographic methods, transnational cooperation, language knowledge as critical language awareness, also as citizens of the world, and knowledge of culture and Society and critical cultural awareness, as well as citizens of the world. 
According to the Intercultural Communication and Assessment (INCA), there are six dimensions of the IC namely: tolerance for ambiguity, behavioral flexibility, communicative awareness, knowledge discovery, respect for other aspects, and empathy. In conducting the manual assessment, INCA simplifies the six dimensions of the IC into three, namely openness, knowledge, and adaptability (Byram, Kuhlmann, Muller, Jacquier, and Budin as quoted by Shoman and Mahmoud M, 2011: 39-40). Fantini (2006) and Edi (2016) focused on knowledge (positive), attitude/influence, skill, awareness, and behavior.

\section{3) The Concept of Attitude}

Attitude has a close relationship with motivation and interconnected each other. Rinantanti (2015, p.93) asserts that attitude is one of an important element of learning a language. Attitude is belief and opinion that can influence individuals to behave in a certain way (Ellof and Ebersohn, 2004, p.35). Attitude is characterized by a large proportion of emotional involvement such as feelings, self, and the relationship in the community (Brown, 2001, p.61). Attitude is an evaluative reaction to some reference objects that are inferred based on individual beliefs or opinions about referrals. Attitudes are gained through experience and have a direct effect on behavior (Bin-Tahir, 2015a, p.210). A strong and positive attitude can predict behavior that is more effective than weak or negative, and attitudes shaped by personal experience are often stronger in nature (Bin-Tahir, 2015b, p. 45).

Student attitude is commonly believed to hold a central role in ICC. The attitudes towards the target culture those are learned by students will greatly affect the students' motivation level in learning the target language. The positive attitude will sustain students in learning foreign languages and will also be part of the successful language learning outcomes from the non-linguistic field. Byram (1997, p.34) asserts that attitude (as the prerequisite for intercultural interaction) which is necessary for successful intercultural interaction not only the positive attitudes (positive prejudices can hinder the mutual understanding) such as openness, belief in the behavior of others, but it also requires a sense of full of curiosity, distrusting people's behavior and judging the meaning. Byram (1997, p.50) emphasizes that attitudes that are part of intercultural communicative competence are an inquisitive feeling about something and the openness and readiness to delay distrust of other people's cultures and beliefs. Thus, it can be said that attitude is a person's disposition or mental. As an ICC component, attitudes include tolerance of ambiguity, empathy, and non-judgment. According to Nakayama (2010, p.469), someone's attitude contributes to the competence of intercultural communication, including tolerance of ambiguity, empathy, and non-judgment.

\section{4) The Concept of Knowledge}

Knowledge can be defined as facts or information acquired by a person through experience or education. It can also be defined as the theoretical or practical understanding of a subject (Rinantanti \& Suhirman, 2017, p.106). In the context of ICC knowledge refers to the individual and social group, practice with people who have the different culture to improve the knowledge of ICC (Byram, 1997, p.35). They are two types of knowledge required for ICC. Firstly is knowledge of the social groups and the culture in one's country and in the one's interlocutor's countries. Secondly is the knowledge of the processes of interaction at societal and individual levels.

The knowledge component consists of various aspects of cognitive communication competence. This involves what we know about ourselves and others and about the various aspects of communication. Knowledge related to the competence of intercultural communication, knowledge of how people from other cultures think and behave will also help someone becomes more effective communicators (Nakayama, 2010, p.468). There are two broad categories of the cultural knowledge that the language learners required. First, is the knowledge about the social groups, what they practiced and produced both at their own culture and the other cultures. Second, is the knowledge about the process of interaction both at the individual and community level (Byram, 1997, p.35).

\section{5) The Concept of Skills}

Skills are the abilities acquired in the form of innate that is perfected in learning and practice. Skills can occur in various areas of life, whether in the field of science, art, manual activity and so forth. Everyone has basic skills that can be improved by training, persistence, and effort. There are also people who do not have the ability to learn but are very good at other fields. Learners need to have skills that suit their ability. Learners who have the ability to interact with people who have the same or different cultures are part of the communication skills. Byram puts forward two sets of skills, which reflect the two general categories. Firstly, the skills to interpret and relate: the ability in interpreting, explaining and correlating a document from one's own culture or event from another culture. Secondly, the skills to discover and interact: the ability in gaining new cultural knowledge and practices as well as the ability in operating knowledge, attitudes, and skills within the real-time communication and interaction constraints.(Byram, 1997, p. 52).

\section{6) The Concept of Awareness}

Awareness is a social activity that receives signals from the people around to be able to influence each other in order to achieve greater mutual awareness. Awareness as a characteristic of systematic action achieves to increased daily activities. Meanwhile, Tomlison and Masuhara (2004) assert that intercultural communication will result in cultural understanding and sense of cultural equality itself. According to them, intercultural communication can enhance the cultural understanding, the sense of cultural equality and facilitate the language learning through the provision of a positive and empathetic learning experience that provides motivational exposure to the language use (Tomlison and Masuhara, 2004, p.7). While intercultural awareness according to Knapp and Meierkord (2002, p.22-23) is a conscious understanding of the role of culture-based forms, practices, and frameworks in intercultural communication, and the 
ability to apply these conceptions flexible and specifically within the context of communication in real time. Tomalin and Stempleski (1993, p.3) identify the three elements deemed necessary in the quality of cultural awareness. They are the awareness of their own cultural behavior, the awareness of the cultural behavior of others and the ability to explain cultural perspectives with regard to this, Byram asserts that a critical cultural awareness is one's ability to critically evaluate and based on the perspectives, practices, and products of explicit criteria in one's culture and other cultures (1997, p.233).

\section{Strategies to Develop ICC}

\section{1) Definition and Strategy Competence}

A strategy is a planned series of actions for achieving something. The strategy in the educational context can be defined as a plan, method, or series of activities designed to achieve a particular educational goal. The strategies of learning include all the ways those directly correlated to learning (cognitive) or those indirectly involve in the process of learning (meta-cognitive) (Rubin, 1987). There are five ways that can be used to learn a language. These strategies are management and planning, cognitive, communicative-experiential, interpersonal, and effective. The purpose of communication-experiential strategy according to Stern, (1992) is to direct the overflow of communication. According to Canale and Swain (1980, p.30), strategic competence can be described as strategies of both verbal and non-verbal communication that can be used to compensate the breakdown of the communication due to the learners' performance variables or the learners' insufficient competence.

2) Models and Strategies in ICC

Strategies are often consciously and purposefully combined; however, in other cases, the choice of specific evaluative modes sometimes naturally combines strategies. The various strategies and tools are employed throughout the process to ensure a more accurate, more complete, and more reliable assessment result (Fantini, 2000, 2001, and 2006). Assessing intercultural competence requires the combined use of a variety of modes and strategies as the following: (1) Strategies that involve objective scoring; (2) Oral and written activities; (3) Active and passive activities; (4) Individual and interactive activities in pairs or small groups; (5) Dialogs, interviews, presentations, etc; (6) Demonstrations, poster sessions, simulations, role plays; (7) Structured and unstructured field tasks and other experiential activities; and (8) Questionnaires that require self-evaluation, peer evaluation, group evaluation, teacher evaluation, and/or host evaluation (triangulation).

\section{METHOD}

The study used qualitative methods by applying grounded theory design. The researchers investigated the student's strategies in developing the ICC model. Data were obtained from participant observation, interview, field note, and audio recording as well as documentation. There were four English study program students of STKIP Yapis DompuNTB (AM, YA, AS, and ED) involved in this research. The students generally come from various tribes in the east of Indonesia with different ethnics, gender, social, cultures, and languages. The data gained were analyzed descriptively.

\section{FINDINGS AND DISCUSSIONS}

The study revealed that:

\section{A. Students A.M. Has Sixteen Strategies in Developing ICC Model}

His strategies were: (1) Creating a comfortable feeling when talking with people who have different languages and cultures (skill); (2) Creating a pleasant situation when communicating with people from different languages and cultures (skill); (3) Showing a polite attitude toward foreigners (attitude); (4) Showing the knowledge of social groups (attitude); (5) Showing the skill to understand people from different cultures (skill); (6) Being aware of a negative actions of people who have a different languages and cultures (awareness); (7) Changing to nonverbal behavior such as eye contact when the situation requires it (behavior); (8) Building a serious communication when people of different languages and cultures that are not paying attention (skill); (9) Using slang when speaking to people from certain countries like Australia and Japanese and speaking using formal language in a slowly (skill); (10) Respecting and appreciating the different (attitude); (11) Creating a cozy atmosphere (skill); (12) Providing an opportunity to speak (skill); (13) not changing the topic when foreigners are talking (skill); (14) Respecting their science, knowledge, and religion (attitude); (15) Following the direction of the conversation and not allowed to come out of the contents of the conversation (attitude); (16) Participating in the various conference including national and international on cultural diversity (awareness).

\section{B. Students Y.A. Has Nine Strategies in Developing ICC Model}

His strategies were (1) to understanding the contents of the conversation (knowledge); (2) Explaining something with a single words (skill); (3) Understanding the attitude, knowledge, skills, and awareness as a basic communication with people who have different languages and cultures (knowledge); (4) Changing to nonverbal behaviors such as eyes contact when situations require it (behavior); (5) Changing to nonverbal behavior when getting difficult to communicate (skill); (6) Controlling nonverbal behavior based on one's own culture (skill); (7) Using body language to solve 
problems (skill); (8) Teach in abroad at elementary school, junior high school, and senior high school (skill); (9) Participating in national and international conference (awareness).

\section{Students A.S. Has Seven Strategies in Developing ICC Model}

His strategies were (1) Knowing the contents of the conversations (knowledge); (2) Listening to what they have to say (skill); (3) when strangers give advice based on their culture, if it does not fit to our culture, then we give an explanation according to our culture (knowledge); (4) Knowing clearly the attitude, knowledge, skills, and awareness even behavior as a basic communication with people from different languages and cultures (knowledge); (5) Changing to nonverbal behavior like eyes contact when communicating with people from different languages and cultures (behavior); (6) Using nonverbal behavior based on situations and conditions (skill); (7) Participating in national and international conference continuously (awareness).

\section{Students E.D. Has Ten Strategies in Developing in ICC Model}

His strategies were (1) Showing a good attitude towards foreigners (attitude); (2) Showing a good personality towards foreigners (attitude); (3) Communicate with polite words (skill); (4) Act reflexively to please the foreigners (skill); (5) Knowing that the attitude, knowledge, skills, and awareness even behavior as a basic communication when communicate with people from different languages and cultures (knowledge); (6) Using nonverbal behavior such as eyes contact when situation requires it (behavior); (7) Using nonverbal behavior when getting difficulty in communicating with people who have a different languages and cultures (skill); (8) Participate in national and international conferences (awareness); (9) Studying in abroad (awareness); (10) Studying informally through Youth Exchange programs (awareness).

Based on the findings of this study, the strategies used in improving students' ICC were dominated by the skills dimension with eighteen strategies, followed by the attitude and awareness dimension with seven strategies, and the knowledge and behavior dimension with 6 and 4 strategies respectively.

A.M. participant has the same strategy with E.D. In the attitude dimension both participants used showing a polite attitude toward foreigners. Y.A. and A.S. had the same strategy in the dimension of knowledge. Both of them used knowing the content of the conversation. Participants Y.A., A.S. and E.D. had the same strategies in the dimension of knowledge. They used understanding the attitude, knowledge, skills, and awareness as a basic communication with people who have different languages and cultures. Participants Y.A., A.S. and E.D. had the same strategies in the skills dimension those were changing to nonverbal behavior when facing difficulties to communicate. Participants A.M. Y.A., A.S. and E.D. had the same strategies in the awareness dimension. They used participating in the various conferences including national and international on cultural diversity and the last participants A.M. Y.A., A.S. and E.D., had the same strategies in the behavior dimension. They used changing to nonverbal behavior such as eye contact when the situation requires it.

The participants of this research had different strategies for increasing ICC. A.M. participant had four strategies in attitude dimensions to increase the ICC. These strategies were (1) Showing knowledge of social groups; (2) Respecting and appreciating the different; (3) Respect their science, knowledge, and religion; (4) Following the direction of the conversation and not allowed to come out of the contents of the conversation. E.D. participant had one strategy in attitude dimension that was showing a good personality towards foreigners. Y.A. and A.S. participants did not have a different strategy in the attitude dimension. A.M, Y.A, AS, and E.D participants did not have different strategies in the knowledge dimension. A.M. Participant had eight different strategies on the skill dimension. Those strategies were (1) Creating a comfort feeling when talking with people who have different languages and cultures; (2) Creating a pleasant situation when communicating with people from different languages and cultures; (3) Showing the skill to understand people from different cultures; (4) Building a serious communication when people of different languages and cultures that were not paying attention; (5) Using slang with people from certain countries like Australia and Japanese and speaking using formal language slowly; (6) Creating a cozy atmosphere; (7) Providing an opportunity to speak; (8) not changing the topic when foreigners are talking. Participant Y.A. had four different strategies on the skills dimension. They were (1) Explaining something with a single word; (2) Controlling nonverbal behavior based on one's own culture; (3) Using body language to solve problems; (4) Teaching at the elementary school, junior high school, and senior high school abroad. A.S. participant had two different strategies on the skills dimension. These were (1) Listening to what they have to say; (2) If foreigners give suggestions, give them advice. A.S. Participant had two different strategies on the skills dimension, those were (1) Communicating with polite words; (2) Act reflexively to please the foreigners. A.M. Participant had one different strategy on the awareness dimension. It was being aware of negative actions of people who have different languages and cultures. E.D. Participant had two different strategies on the awareness dimension. They were (1) Studying abroad; (2) Studying informally through Youth Exchange programs. Y.A. and the A.S. Participant did not have different strategies in the dimensions of awareness. All participants did not have strategies that differ in the behavioral dimension.

\section{CONCLUSIONS}


The findings of the research indicated that the way the students of English study program of STKIP Yapis DompuNTB developed ICC model encompasses attitude, knowledge, skills, awareness, and behavior. The individual participant had his own strategies in improving the ICC model. A.M. Participant had sixteen strategies to develop ICC model, Y.A. had nine strategies, A.S. had seven strategies and E.D. has ten strategies.

\section{REFERENCES}

[1] Adrian Holliday, M. H. and J. K. (2010). Intercultural Communication: An Advanced resource book for students. (R. C. and W. H. Christopher N. Candlin, Ed.) (Second Ed.). USA-Canada: Routledge Taylor and Frances Group.

[2] Bin Tahir, SZ. (2015a). The Attitude of Santri and Ustadz toward Multilingual Education at Pesantren. International Journal of Language and Linguistics. Volume 3(4). 210-216.

[3] Bin Tahir, SZ. (2015b). Multilingual Behavior of Pesantren Immim Students in Makassar. Asian EFL Journal. Volume 86, p.p. 45-64.

[4] Brown, J. D. (2001). Using surveys in language programs. Cambridge: Cambridge University Press.

[5] Byram, M., Gribkova, B. \& Starkey, H. (2002). Developper La Dimension Interculturelle de l'enseignement des langues. Division des politiques linguistiques, Conseil de l'Europe, Strasbourg. Langue's vivantes.

[6] Byram, M., Nichols, A. and Stevens, D. (Eds.). (2001). Developing Intercultural Competence in Practice. Clevedon: Multilingual Matters.

[7] Byram, M. (1997). Teaching and assessing intercultural communicative competence. Clevedon: Multilingual Matters.

[8] Chrystal, David. (2000). Language Death. Cambridge: Cambridge University Press

[9] Canale, Michael, and Merrill Swain. (1980). 'Theoretical bases of communicative approaches to second language teaching and testing'. Applied Linguistics, 8/8: 1-47.

[10] Durant, A. (1997). Facts and meanings in British Cultural Studies. In: Bassnett, S. (Ed.), Studying British Cultures. An Introduction (pp. 19-38). London: Routledge.

[11] Edi. (2016). Developing Intercultural Communicative Competence Model for English Students in Indonesia University Context. Asian EFL Journal. Volume 10. 125-148.

[12] Ellof, I. \& Ebersohn, L. (2004). Keys to educational Psychology. Cape Town: UCT Press.

[13] Fantini, (2000-2001). 'Designing quality intercultural programs: a model and a process', Interspectives: A Journal of Transcultural Education, 18: 100-105.

[14] Fantini, (2006). Exploring and Assessing Intercultural Competence, Brattleboro, VT: Federation EIL. Online. Available: www.experiment.org/resources.html (accessed 1 Oktober 2016).

[15] Franklin, H. S.-O. and P. (2009). Intercultural Interaction. (C. N. C. and D. R. Hall, Ed.). New: Palgrave Macmillan in the US is a division of St Martin's Press Llc.

[16] Gradol, D. (2000). The future of English? a Guide to forecasting the popularity of the English Language in the $21^{\text {st }}$ century. New York: The British Council.

[17] Guilherme, M. (2000). Intercultural competence. In M. Byram (ed.) Routledge Encyclopaedia of Language Teaching and Learning (pp. 297-300). London: Routledge.

[18] Kendall, D. (2001). Sociology in our times. 3rd ed. Belmont, CA: Wadsworth/Thomson Learning.

[19] Knapp, M. L., \& Hall, J. A. (2002). Nonverbal communication in human interaction (5th Ed.). United States: Wadsworth Thomson Learning.

[20] Nakayama, J. N. M. and T. K. (2010). Intercultural Communication in Contexts (Fifth Edit). New York: McGraw-Hill, a business unit of the McGraw-Hill Companies, Inc., 1221 Avenue of the Americas, New York, NY 10020.

[21] Rinantanti, Y. (2015). Attitudes toward Autonomy in Learning English: a case study in Cenderawasih University Papua Indonesia. The Asian EFL Journal Professional teaching article issue 86. 90-110.

[22] Rinantanti, Y. \& Suhirman, L. (2017). Mapping of the Competence of SHS Students in English Subject in Sarmi and Mamberamo Raya Regencies Papua, Indonesia. The Asian EFL Journal. TESOL Indonesia International Conference Edition, Vol.10. 93-111.

[23] Samovar, L A., Porter, R.E. \& McDaniel, E.R. (2010). Intercultural communication: a reader. 12th ed. Belmont, CA: Wadsworth.

[24] Shoman and Mahmod M. (2011). Developing Intercultural Communicative Competence and Proficiency of Advanced Arabic Learners: A Proposed Framework. The American University in Cairo.

[25] Stern, H. H. (1992). Issues and options in language teaching. Oxford: Oxford University Press.

[26] Tomalin, B. and Stempleski, S. (1993). Cultural awareness. Oxford: Oxford University Press.

[27] Tomlinson, B. and Mashuhara, H. (2004). Developing cultural awareness. Modern English Teacher, 13(1), 5-11

[28] Tuleja, E.A. (2005). Intercultural communication for business: managerial communication. 6th ed. Mason, OH: Thomson South-Western.

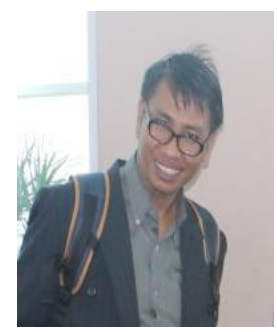

Edi was born in Dompu, Indonesia on October 05, 1980. He graduated his Undergraduate (S)1 from 45 University of Makassar in 2005. His Master Degree (S2) from STIE Malang, Indonesia in 2010, and graduated his doctoral of English Education Department at the State University of Makassar in 2017. Indonesia.

He is a lecturer at English Education Department of the STKIP Yapis Dompu, NTB, Indonesia. He has published the article in Asia EFL such as Developing Intercultural Communicative Competence Model for English students in Indonesia University Context, Asian EFL Journal, Vol 10, 2016; 125-148. Mr. Edi become a member of Asia TEFL, and a head of the STKIP Yapis Dompu, NTB, Indonesia. 


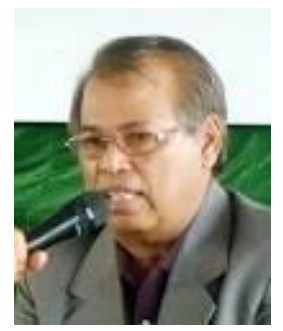

Basri Wello was born in Maroanging, Enrekang, Makassar, Indonesia on November 05, 1952. He is a professor of English Education at English Department of State University of Makassar, Indonesia. He graduated his S1 from IKIP Ujung Pandang in 1977, S2 from the Cansas University of US in 1987 and graduated his doctoral program from Hasanuddin University, Makassar, Indonesia in 1999.

$\mathrm{He}$ is an Education Specialist with over 20 years of experience in the education sector in Indonesia. His various areas of expertise include Curriculum design, design and establishment of the baseline for the school system in Indonesia, school program assessment and evaluation, pre-service and in-service teacher training, school accreditation, teacher certification, and higher education management. In addition, he also an advisor for the planning and implementation of school development programs as well as facilitating community participation at the city and school level from 2008-2012. He was responsible for controlling, evaluating and providing service and technical assistance to 347 private higher education institutions in regional IX Sulawesi. Since 2006 he has been a chairperson for Makassar City Education Council and for the last few years as an Education Specialist, he has been largely involved in Project evaluation funded by USAID namely MBE final Evaluation ( SCECID, USA), DBE Mid-term Evaluation (TMG, USA), DBE Final Evaluation (JBS, USA), Aceh Polytechnique Evaluation and A Gapp Analysis of Teacher Training Institute in Indonesia ( JBS, USA), Indonesian Tracer Study (JBS-USAID), USAID PRIORITAS final Evaluation (MSI-MESP).

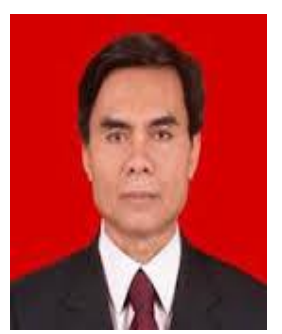

Syarifuddin Dollah was born in Bua-Bua, Pinrang, Indonesia on December 31, 1963. He is currently a lecturer of English Education Department of the State University of Makassar. He graduated his S1 and S2 from IKIP Ujung Pandang in 1996 and graduated his doctoral program from Hasanuddin University, Makassar, Indonesia in 2006.

He has published many articles in his field of study including 1) The Effect of Self-esteem, Anxiety, and Gender on Oral Communication of EFL Students of Universitas Negeri Makassar (2006); 2) Pengembangan Model dan Perangkat Pembelajaran Bahasa Inggris Berbasis Islami dengan Pendekatan "Content-Based Instruction" Siswa Madrasah Tsanawiyah (MTs) di Sulawesi Selatan (Unggulan Perguruan Tinggi) (2016). He also attended and presented many international conferences abroad.

Mr. Dollah is more active in many professional organizations such 1) member of Masyarakat Linguistik Indonesia (MLI) Cabang UNM; 2) Member of Asia TEFL; 3) Member of TEFLIN, and 4) Manager of ADRI SULSEL. Now he is a dean of language and literature faculty of the State University of Makassar, Indonesia. 